\title{
BOUNDARY-LAYER METEOROLOGY
}

\author{
An International Journal of Physical and Biological Processes \\ in the Atmospheric Boundary Layer
}

Editor: R. E. MUNN, Toronto, Ont., Canada

Editorial Board: I. A. Balogun, P. Barry, A. Baumgartner, M. E. Berlyand, W. Böer, T. J. Chandler, R. J. Charlson, K. T. C. Cheng, A. G. Davenport, M. Estoque, H. W. Georgit, L. Hasse, U. Högström, E. Inoue, H. E. Landsberg, E. R. Lemon, H. H. Lettau, M. Miyake, A. S. Monin, D. H. Pack, H. A. Panofsky, J. R. Philip, G. D. Robinson, R. Roth, F. H. Schmidt, T. Sekiguti, V. P. Subrahmanyam, W. Swingank, K. Takeuchi, J. Tomlain, E. Truhlar, P. Ulriksen

Contents of Volume I, No. 4, April 1971:

Helmut Kraus / Turbulent Energy Flux and Eddy Diffusivity. - Charles R. Stearns / The Effect of Time-Variable Fluxes on Mean Wind and Temperature Profile Structure. - F. W. Dobson / The Damping of a Group of Sea Waves. - T. R. Oke and C. East / The Urban Boundary Layer in Montreal. - G. A. McBean / The Variations of the Statistics of Wind, Temperature and Humidity Fluctuations with Stability. - J. Lomas, E. Schlesinger, and A. Israeli / Leaf Temperature Measurement Techniques. - B. R. Bean et al./ Preliminary Results of Utilizing the High Resolution-FM Radar as a Boundary-Layer Probe. - P. A. Taylor / Airflow above Changes in Surface Heat Flux, Temperature and Roughness; an Extension to Include the Stable Case.

Book Review.

Index of Subjects.

Subscription price per volume of 4 issues Dfl. 144,80 (US $\$ 40.55$ ) including postage. One volume is published yearly / Personal subscription price on request.

\section{REIDEL PUBLISHING COMPANY}

DORDRECHT-HOLLAND 


\author{
Edited by
}

\begin{abstract}
J. E. Blamont, R. L. F. Boyd, L. Goldberg, C. de Jager, Z. Kopal, G. H. Ludwig, R. Lüst,
B. M. McCormac, H. E. Newell, L. I. Sedov, Z. Svestka, and W. de Graaff
\end{abstract}

1. C. de Jager (ed.), The Solar Spectrum. Proceedings of the Symposium held at the University of Utrecht, 26-31 August, 1963. 1965, XIV + 417 pp.

2. J. Ortner and H. Maseland (eds.), Introduction to Solar Terrestrial Relations. Proceedings of the Summer School in Space Physics held in Alpbach, Austria, July 15-August 10, 1963 and Organized by the European Preparatory Commission for Space Research. 1965, IX + 506 pp.

3. C. C. Chang and S. S. Huang (eds.), Proceedings of the Plasma Space Science Symposium, Held at the Catholic University of America, Washington, D.C., June 11-14, 1963. 1965, IX +377 pp.

4. Zdeněk Kopal, An Introduction to the Study of the Moon. 1966, XII +464 pp.

5. Billy M. McCormac (ed.), Radiation Trapped in the Earth's Magnetic Field. Proceedings of the Advanced Study Institute, Held at the Chr. Michelsen Institute, Bergen, Norway, August 16September 3, 1965. 1966, XII + 901 pp.

6. A. B. Underhill, The Early Type Stars. 1966, XIII + 282 pp.

7. Jean Kovalevsky, Introduction to Celestial Mechanics. 1967, VIII + 427 pp.

8. Zdeněk Kopal and Constantine L. Goudas (eds.), Measure of the Moon. Proceedings of the Second International Conference on Selenodesy and Lunar Topography held in the University of Manchester, England, May 30-June 4, 1966. 1967, XVIII + 479 pp.

9. J. G. Eunming (ed.), Electromagnetic Radiation in Space. Proceedings of the Third ESRO Summer School in Space Physics, held in Alpbach, Austria, from 19 July to 13 August, 1965. 1968, VIII +307 pp.

10. R. L. Carovillano, John F. McClay, and Henry R. Radoski (eds.), Physics of the Magnetosphere. Based upon the Proceedings of the Conference held at Boston College, June 19-28, 1967. 1968 $\mathrm{X}+686 \mathrm{pp}$.

11. Syun-Ichi Akasofu, Polar and Magnetospheric Substorms. 1968, XVIII + 280 pp.

12. Peter M. Millman (ed.), Meteorite Research. Proceedings of a Symposium on Meteorite Research held in Vienna, Austria, 7-13 August, 1968. 1969, XV +941 pp.

13. Margherita Hack (ed.), Mass Loss from Stars. Proceedings of the Second Trieste Colloquium on Astrophysics, 12-17 September, 1968. 1969, XII + 345 pp.

14. N. D'Angelo (ed.), Low-Frequency Waves and Irregularities in the Ionosphere. Proceedings of the 2nd ESRIN-ESLAB Symposium, held in Frascati, Italy, 23-27 September, 1968. 1969, VII + 218 pp.

15. G. A. Partel (ed.), Space Engineering. Proceedings of the Second International Conference on Space Engineering, held at the Fondazione Giorgio Cini, Isola di San Giorgio, Venice, Italy, May 7-10, 1969. 1970, XI + 728 pp. 
16. S. Fred Singer (ed.), Manned Laboratories in Space. Second International Orbital Laboratory Symposium. 1969, XIII +133 pp.

17. B. M. McCormac (ed.), Particles and Fields in the Magnetosphere. Symposium Organized by the Summer Advanced Study Institute, held at the University of California, Santa Barbara, Calif. August 4-15, 1969. 1970, XI+450 pp.

18. Jean-Claude Pecker, Experimental Astronomy. 1970, X +105 pp.

19. V. Manno and D. E. Page (eds.), Intercorrelated Satellite Observations related to Solar Events. Proceedings of the Third ESLAB/ESRIN Symposium held in Noordwijk, The Netherlands, September 16-19, 1969. 1970, XVI +627 pp.

20. L. Mansinha, D. E. Smylie and A. E. Beck, Earthquake Displacement Fields and the Rotation of the Earth. A NATO Advanced Study Institute Conference Organized by the Department of Geophysics, University of Western Ontario, London, Canada, June 22-28, 1969. 1970, XI + 308 pp.

21. Jean-Claude Pecker, Space Observatories. 1970, XI +120 pp.

22. L. N. Mavridis (ed.), Structure and Evolution of the Galaxy. Proceedings of the NATO Advanced Study Institute, held in Athens, September 8-19, 1969. 1971, VII + 312 pp.

23. A. Muller (ed.), The Magellanic Clouds. A European Southern Observatory presentation: principal prospects, current observational and theoretical approaches, and prospects for future research. Based on the Symposium on the Magellanic Clouds held in Santiago de Chile, March 1969, on the occasion of the Dedication of the European Southern Observatory. 1971, XII $+189 \mathrm{pp}$.

24. B. M. McCormac (ed.), The Radiating Atmosphere. Proceedings of a Symposium organized by the Summer Advanced Study Institute, held at Queen's University, Kingston, Ontario August 3-14, 1970. 1971. XI + 455 pp.

25. G. Fiocco (ed.), Mesospheric Models and Related Experiments. Proceedings of the 4th ESRINESLAB Symposium, held at Frascati, Italy, July 6-10, 1970.

26. I. Atanasijevic, Selected Exercises in Galactic Astronomy.

27. C. J. Macris (ed.) Physics of the Solar Corona. Proceedings of NATO Advanced Study Institute on Physics of the Solar Corona, held at Cavouri-Couliagmeni, Athens, Greece, 6-17 September 1970.

In preparation:

28. F. Delobeau, The Environment of the Earth.

SOLE DISTRIBUTORS FOR U.S.A. AND CANADA:

SPRINGER-VERLAG NEW YORK, INC., 175 Fifth Ave,, New York, N,Y. 10011 


\title{
SPACE LIFE SCIENCES
}

\author{
An International Journal of Space Biology and Medicine
}

Editor-in-chief: RICHARD L. MASTERS (Albuquerque, N.M., U.S.A.)

Associate Editors: Geoffrey Eglinton (Bristol) and Cyril Ponnamperuma (Moffett Field, Calif.)

Editorial Board: W. R. Adey (Los Angeles, Calif.), E. Barghoorn (Cambridge, Mass.), C. Berry (Houston, Texas), R. Braams (Utrecht), M. Calvin (Berkeley, Calif.), P. E. Cloud, Jr. (Santa Barbara, Calif.), M. Florkin (Liège), O. G. Gazenko (Moscow), S. A. Gordon (Argonne), E. H. Graul (Marburg), A. A. Gurdjian (Moscow), F. Halberg (Minneapolis, Minn.), A. A. Imsenetskij (Moscow), C. de Jager (Utrecht), P. Karlson (Marburg/Lahn), H. P. Klein (Moffett Field, Calif.), C. J. Lambertsen (Philadelphia, Pa.), W. F. Libby (Los Angeles, Calif.), P. O'B. Montgomery (Dallas, Texas), H. Fernandez Moran (Chicago, Ill.), A. I. Oparin (Moscow), N. Pace (Berkeley, Calif.), O. E. Reynolds (Washington, D.C.), S. S. Stevens (Cambridge, Mass.), S. P. Vinograd (Washington, D.C.).

Contents of Volume 3, No. 1, August 1971

J. Skujinš and A. D. McLaren / Urease Reaction Rates at Low Water Activity R. H. Green, D. M. Taylor, E. A. Gustan, S. J. Fraser, and R. L. Olson / Survival of Microorganisms in a Simulated Martian Environment - R. J. von Baumgarten, G. Baldrighi, J. Atema and G. L. Shillinger, Jr. / Behavioral Responses to Linear Accelerations in Blind Goldfish. I: The Gravity Reference Response - R. A. Horne / On the Unlikelihood of Non-Aqueous Biosystems R. R. Stoecker / Survival of Blue-Green Algae under Primitive Atmospheric Conditions - Richard G. Cornell and Ashok K. Bansal / Exponential Decontamination Models for Count Data - P. W. Banda and C. Ponnamperuma / Polypeptides from the Condensation of Amino Acid Adenylates - R. T. Dillon, Diana Holdridge, J. R. Puleo, and G. S. Oxborrow / A Computerized Bacterial Identification System as Applied to Planetary Quarantine.

Subscription price per volume of 4 issues Dfl. 146,50 (US $\$ 42.49$ ) including postage.

One volume is published yearly / Personal subscription price on request.

\section{REIDEL PUBLISHING COMPANY}

\author{
DORDRECHT-HOLLAND
}




\section{Information for Authors}

Celestial Mechanics is an international journal established for the publication of contributions from this field in its broadest classification. Authors are invited to submit manuscripts concerned with the mathematical, physical and computational aspects of this branch of science. Generally this pubblication is open to articles, notes, announcements, letters and information of general interest to the subscribers. No significant contribution will be editorially declined, due to size, so long as it can be printed in a single issue.

Manuscripts should be submitted in triplicate. Send two copies directly to the International Editor or the member of the Editorial Committee you prefer to be the Editor-in-Chief for your manuscript. You may also suggest possible referees knowledgeable in the subject of your manuscript. The suggested referees, if well qualified, will often be used. Papers approved by your selected editor will be published without further review. (If the author wishes, he may send all three copies to the executive editor.) Send the third original copy to the executive editor of the journal, Box 95, Greenbelt, Md. 20770, U.S.A., accompanied by a letter (send a carbon of the letter to the selected editor) of transmittal, requesting publication, noting an address to be used for future correspondence with the author, and including the name of the editor selected. This letter should note whether the paper (or some version of it) has been published elsewhere - frequently a release must be obtained from the previous publisher. Also, material submitted must not have a security classification.

Manuscripts should be typed (double-spaced) on one side of plain paper, with wide margins to allow for editorial notes and instructions to the printer. Equations and symbols should be typed if possible; in each case, clarity is essential. Unusual symbols should be identified in the margin. Care should be taken to distinguish between the letter ' $O$ ' and zero; the letter ' $l$ ' and the number one; kappa and $\mathrm{k}$, $\mathrm{mu}$ and the letter $\mathrm{u} ; \mathrm{v}$ and $\mathrm{nu} ; \mathrm{n}$ and eta; also subscripts and superscripts should be clearly noted and easily distinguished. Each contribution should be as concise as the proper presentation of ideas will allow, keeping in mind that Celestial Mechanics is a specialist journal and the reader is likely to be well acquainted with the usual academic references. The first page of the manuscript should contain the title, author's name, affiliation, and official title. Following this information should be an abstract (not an introduction) setting forth the basic ideas, and the primary results obtained. In those cases where the paper is not written in an official language of the IAU, the abstract should be of sufficient length, such that a descriptive translation can be provided for the readers; multi-language abstracts are encouraged. The editors of Celestial Mechanics are not responsible for the disposition of accepted manuscripts after publication of an article in the journal.

Tables are to be numbered consecutively; each should have a title, and should be organized so that they may be placed on a page of the journal in the usual manner. Please avoid the use of vertical lines when possible.

Footnotes for the tables should appear below the final double rule and should be indicated by a,b,c, etc. Each table should be referred to in the text.

Figures, illustrations and photographs should be submitted, ready for reproduction without retouching. Care should be given to the lettering, assuring that it is of adequate size to be legible after reduction. Photographs should be prepared as glossy prints for reproduction. Each figure should have a caption, and should be marked on the back with the author's name and the figure number. It is suggested that all captions be typed on (a) separate sheet(s) rather than on the figure itself.

References should be collected at the end of each paper in alphabetical and chronological order. Each reference should be cited in the text; multi-authored references may be indicated there by the first author, followed by 'et al.'. Each reference should contain the author's name (with initials), the year of publication, a suitable abbreviation for the journal, its volume, and the pages referred to. Quotation of the paper's title is optional. Multiple listings for the same author may be indicated by the use of suffixes $a, b$, etc., following the date of publication.

Proofs. Each author of an accepted contribution will receive two galley proofs of his article from the publisher, along with an annotated copy of his manuscript. He will be requested to return one proof with corrections, and with the manuscript, to the publisher within one week. In those cases when proofs are not returned promptly, they will be read by the executive editor against a second manuscript copy and returned to the publisher without the author's comments. Page proofs will be read only by the executive editor to assure that corrections have been made, as noted by the authors. Any corrections made at this stage in the procedure must be indicated to the executive editor and not to the publisher.

Care should be taken to assure that all contributions are typographically correct. A few corrections to proofs are acceptable, but authors may be expected to be charged for the cost of making extensive alterations to the text and/or illustrations.

Reprints. Each author will receive, without charge, 25 copies of his article from the publisher. Additional reprints may be ordered when the galley proofs are returned to the publisher. 
Preface

B. EMERSON and G. A. WILkins / Proceedings of IAU Colloquium No. 9,

The IAU System of Astronomical Constants, Heidelberg, 127

12-14 August $1970 \quad 128$

WALTER FRICKE / Determinations of Precession (Invited Review Paper) 150

S. VASilevskis and A. R. Klemola / On the Correction to Precession from

Proper Motions Referred to Galaxies

163

SHINKO AOKI and CHUICHI KAKUTA / The Excess Secular Change in the

Obliquity of the Ecliptic and its Relation to the Internal Motion

of the Earth

T. C. VAN FLANDERN / Notes on Equinox Motion and Corrections to

Precession

182

R. O. VICENTE / Observed and Theoretical Values of the Nutations 186

'P. MELCHIOR/Precession-Nutations and Tidal Potential 190

JEAN KOVALEVSKY / Détermination des masses des planètes

(Invited Review Paper)

R. L. DUNCombe, W. J. KLePCZyNSKI, and P. K. Seidelmann / A Determi-

nation of the Masses of the Five Outer Planets

J. H. LIESKE, W. G. MELBOURNE, D. A. O'HANDLEY, D. B. HOLDRIDGE,

D. E. JOHNSON, and W. S. SINCLAIR / Simultaneous Solution for the

Masses of the Principal Planets from Analysis of Optical, Radar, and

Radio Tracking Data

J. SChUBART / The Planetary Masses and the Orbits of the First Four Minor Planets

H. SCHOLL / Correction to the Mass of Jupiter Derived from the Motion of

(153) Hilda, (279) Thule, and (334) Chicago

W. J. KLEPCZYNSKI, P. K. SEIDELMANN, and R. L. DUNCOMBE /

The Masses of the Principal Planets

A. M. SINZI / Corrections to the Lunisolar Precession and the Motion of the

Equinox from Proper Motions of Cepheids

A. BEC / Sur l'effet d'une correction de la constante de la précession

J. KovalevSKy / The 1964 IAU System and the Geodetic Reference

System 1967 